\title{
DEVELOPMENT OF A MOBILE LEARNING APPLICATION OF MALAY VOCABULARY FOR LOWER SECONDARY SCHOOL LEVEL
}

\author{
Nor Zuhaidah Mohamed Zain ${ }^{1}$, Maizatul Hayati Mohamad Yatim ${ }^{1}$, Ummu Husna \\ Azizan $^{1}$ and Hasrina Baharum ${ }^{2}$ \\ ${ }^{1}$ Department of Computing, Faculty of Arts, Computing and Creative Industry, Universiti \\ Pendidikan Sultan Idris, Malaysia \\ norzu@fskik.upsi.edu.my, maizatul@fskik.upsi.edu.my, ummuhusna@fskik.upsi.edu.my
}

${ }^{2}$ Department of Language and Malay Literature, Faculty of Language and

Communication, Universiti Pendidikan Sultan Idris, Malaysia

hasrina@fbk.upsi.edu.my

\begin{abstract}
Modern technology has become an integral part of education field. Undeniably, the use of multimedia technology has a major impact on teaching and learning $(T \& L)$ process of the new generation. This article focuses on designing and developing a mobile learning application of Malay vocabulary for lower secondary school level. The design and development of the application called "Kuasa Kosa Kata" ( 3 K henceforth) was based on a novel entitled "Sejambak Bakti". The context of this study is closely related to game-based learning (GBL) method in the $3 K$ application that encourages independent learning among the targeted students. Designing the $3 K$ application was based on a storyboard for the idea and story-making whilst the development of it was done using Adobe Flash. The data on participants' comments and opinions on the learning application were qualitatively gathered from semi-structured interviews. As conclusion, focus is on the importance of game-based learning implementation in the development of mobile learning application. It is hoped that use of $3 \mathrm{~K}$ application as teaching material will boost the mastery of Malay Language vocabulary among lower secondary school students.
\end{abstract}

\section{KEYWORDS}

Teaching and learning, mobile learning application, game-based learning, Malay vocabulary, lower secondary school.

\section{INTRODUCTION}

Language learning, be it learning about literature or vocabulary, can be fun when the lessons are delivered in an engaging manner to targeted learner. The use of multimedia technology has a major impact on the teaching and learning (T\&L henceforth) process of the new generation, thus providing a platform that allows the invention of digital natives. In this digital world, mobile technology and learning are inevitably intertwined, thus requiring an education theory that directly addresses this changing digital education landscape [1]. A study by [2] found that integration of modern technology in the T\&L process of the Arabic language increased students' motivation to learn. The integration has initiated an opportunity for educators to explore and getting updated on the use of technology in the current educational landscape. For example, educators can use digital educational games as an exciting approach which could provide full of 
knowledge building of $\mathrm{T} \& \mathrm{~L}$ environment [3]. Hence, this approach can be considered for additional materials for educators.

Since to date, [4] acknowledges quality education as one of Sustainable Development Goals (SDG), as there are 617 million youth worldwide who lack on basic mathematics and literacy skills. Since education enables upward socioeconomic mobility and acts as a key to escaping poverty, all parties should play their roles to achieve SDG's fourth goal. According to [4], education is at the root of SDG4, which aims to ensure education for all, starting from the basic education. Two out of the six objectives in SDG4 clearly state the need to increase the number of trained and qualified teachers and to promote education for sustainable development. Hence, one of the achievable approaches is found through the variations of T\&L material for education in and outside the classroom setting.

To uphold this, Malaysia's government has launched The 2013-2025 Malaysia Education Blueprint Report with eleven shifts, including seventh shift: leveraging Information and Communication Technology (ICT) to scale up quality learning across Malaysia [5]. One of the outlined approaches is to maximise the use of ICT for distance and self-paced learning to expand capacity that allows for more customised learning. The report also emphasised that in order to realise the country's aim of creating ICT-literate human capital, technology infrastructure in education needs to be improved, especially in current T\&L method [6]. This initiative shows the seriousness of Malaysia's government in transforming the education environment to a better pace. At the same time, its citizens should play respective role to ensure the initiative be a success achievement.

Several number of research problems need to be overcome in order to fulfil this study need. Firstly, teachers in Malaysia, especially Malay language teachers in secondary school are mostly struggled to develop proper learning material or a mobile learning application (MLA) due to lack of development skills. Being literate in the Malay language is fundamental because the language functions as the primary language of instruction and knowledge in the Malaysian education system [7]. Meanwhile, as reported by [8] from their observations, some students were still unable to properly spell or apply the vocabulary they learnt due to the limited exposure of the target vocabulary during the learning process in the classroom. Consequently, even at the secondary school level, students who are struggling with vocabulary need an intervention in order to improve their language skills, particularly in writing or speaking. Thus, [9] believed that the use of ICT in Malay language T\&L can be perceived as a good effort that capable to give a good impact towards addressing some learning issues, and aims to uphold Malaysia's insistence towards the transformation of T\&L approach in this new digital world.

Currently, almost all level of students in Malaysia, including secondary school students are having tendency to learn using mobile technology, such as smart phone or tablet. This landscape leads to second research problem of this study, which is the lack of learning material in Malay vocabulary for secondary school students. By acknowledging the significance of vocabulary in Malay language literacy and the potential of mobile technology in increasing learning engagement, this study thus applied a game-based learning (GBL) approach through the development of one mobile learning application for learning Malay vocabulary. The main objective of this study is to develop an android mobile learning application entitled "Kuasa Kosa Kata" or $3 \mathrm{~K}$. This objective then has led to two (2) research questions that guided this study, which are:

i) how do students feel when using $3 \mathrm{~K}$ application in learning Malay vocabulary?

ii) what suggestion(s) that students want to propose in improving $3 \mathrm{~K}$ application? 
The International Journal of Multimedia \& Its Applications (IJMA) Vol.12, No. 6, December 2020

For further reading, this paper is organised as follows. In Section 2, the literature is presented into towards three (3) gist of discussion; (i) Malay vocabulary knowledge among students, (ii) learning material for vocabulary learning, and (iii) game-based learning. Section 3 provides the details of design and development of $3 \mathrm{~K}$ mobile learning application. Followed up by Section 4, this section discussed the finding from testing phase with selected participants. Finally, the paper concludes with a discussion on the contribution, limitation and recommendation of the study.

\section{Literature REVIEW}

Several numbers of previous researches have discussed about Malay vocabulary among lower level students, learning material for vocabulary learning and game-based learning concept. Further discussion points are as following:

\subsection{Malay Vocabulary Knowledge Among form One Students}

All students in government school in Malaysia are encouraged to master the literacy skills of Malay language as early as Standard One in primary school. For secondary school level, a component of arts or literature, or "Komponen Sastera" as it is known in Malay (KOMSAS henceforth), was introduced by the Centre of Curriculum Development, Ministry of Education, Malaysia. KOMSAS is one of the important elements in Malay Language, which is a core subject in Malaysian secondary schools. Presently, a novel and an anthology are assigned to lower secondary students for KOMSAS lessons. Novel is chosen from the selection of work in various genres by Malaysian novelists, including classical or modern poems, short stories, and citation or drama citation.

For Form One students, the selected novel was "Sejambak Bakti", written by Rejab F.I., who is one of Malaysian famous authors. As quoted by [10], this novel encompasses multicultural education elements that capable to inculcate the spirit of unity among the multiracial students in Malaysia. The storyline offers an opportunity for students to understand the cultural differences thus initiating harmony and a respectable relationship between the races. Characters from various races exemplify the good attitude of being respectful and helpful in an interesting and easy-tounderstand storyline [11].

Effective vocabulary teaching requires teachers to adopt a creative and engaging approach in order to sustain students' interests. A number of studies have discussed the need for a creative approach in language teaching. Research related to students' understanding and memory of vocabulary learning in KOMSAS, such as one by [12], has suggested several improvements in order to overcome students that shying away from answering questions concerning KOMSAS, especially in the Malaysia Certificate of Education ("Sijil Pelajaran Malaysia" or SPM).

Besides highlighting the issues of community background, character and characterisation, [12] also reiterated the effectiveness of the scheme model in learning and understanding the aspects of language style. The findings of this study showed that the use of schema model can improve students' understanding of short stories, including aspects of language style. The scheme is designed in students' cognitive structure through the process of understanding, hence enabling them to answer questions on the short story, and emphasis the aspects of the language style better.

In another study on language style aspect, [13] looked at teachers' perceptions of the use of literary language style to teach Malay language, their perceived ability to use this style in teaching, and the actual use of the style in the classroom. The study also found that teachers 
generally agreed to apply literary language styles in their teaching and reciprocally, students were delighted to learn Malay literary materials. Moreover, teachers were interested to apply the literary language style in their teaching, as they believed on its capability stimulate students' interests in learning.

As highlighted by [13], the style of literary language is one of the important aspects in improving students' language skills. However, he also found that there are some problems during the implementation of literary language style in teaching. Majority of teachers in the study stated that time constraint is the issue that appeared while using the literary language style in teaching. Pressed for time, they could not comprehensively carry out their planned T\&L activities in the classroom. This finding led to [13]'s study in suggesting teachers to devise and master suitable teaching techniques in order to deal with time issue.

Meanwhile, [14] investigated students' level of understanding regarding of language style aspect in KOMSAS. Based on findings, the researcher reviewed and suggested for appropriate, accurate, and interesting teaching activities that allow them to teach every aspect of language style such as metaphor and personification. Studies discussed in this section often highlighted the similar aspects of language learning, that increase students' understanding and vocabulary retention in KOMSAS as requiring a more interesting approach. Hence, considering that these students are digital natives, any approach is predicted to be more effective and interesting if it is combined with the use of ICT.

In an effort to enhance the T\&L of Malay language at the lower secondary school level, gamification concept has been introduced to attract students to learn vocabulary. Application that is embedded with game features, such as reward and challenge, has allowed gamification element to be infused in the Malay vocabulary learning for lower secondary school students. This infusion of gaming is in line with the view that stating an education system which embedded with digital game technique is very flexible and provides educators with the advantage of applying the learning principle found in popular learning theories [15]. Hence, learning materials with digital game element could potentially increase students' motivation to learn Malay vocabulary. First and foremost, why vocabulary? Initially, according to [16], vocabulary is fundamental in learning any language, as students are able to read and understand a reading passage in their textbook when they literate with vocabulary words. Thus, vocabulary should be one of the focuses in developing learning material in digital form.

\subsection{Learning Material for Vocabulary Learning}

As stated in Akta Pendidikan 1996 (Education Act 1996), Malay language is a core subject in every primary and secondary school in Malaysia. Thus, mastery of the Malay language among students is always emphasised by Ministry of Education. Unfortunately, [17] reported in their study that some students still struggled to perform satisfactorily in Malay language exams even though the language is taught as a core subject in school. Students felt bored in learning the Malay language due to dull teaching style and typical learning activities. Consequently, a creative teaching method must be practiced during T\&L activity. Learning materials should also be interesting to attract students to learn.

In preparing the content for game-based learning and developing learning materials accordingly, the person or team who directly involved in the development process should first understand gamification approach. There are two gamification approaches in preparing learning materials, either in the format of analogue or digital. In the context of learning material preparation, analogue gamification approach usually involves physical materials such as card, board, tile or 
The International Journal of Multimedia \& Its Applications (IJMA) Vol.12, No. 6, December 2020

verbal approach and those are most often applied in a traditional teacher-centred classroom. T\&L activity in or outside classroom setting supposedly could combine either analogue or digital teaching aid material. Displayed in Table 1 is a meta-analysis of some Malay language vocabulary teaching aid material in analogue (non-electronic) form.

Table 1. Meta-Analysis of Some Analogue Malay Language Vocabulary Teaching Aid Materials.

\begin{tabular}{|l|l|l|}
\hline Article Title & Teaching Aid Material & Findings \\
\hline $\begin{array}{l}\text { Vocabulary learning } \\
\text { through board game [8] }\end{array}$ & $\begin{array}{l}\text { Language game package } \\
\text { consisting of a game } \\
\text { board, illustrated cards and } \\
\text { worksheet }\end{array}$ & $\begin{array}{l}\text { There was a growth in recognising, } \\
\text { identifying and applying vocabulary } \\
\text { through writing or speaking. }\end{array}$ \\
\hline $\begin{array}{l}\text { Language Game } \\
\text { Activity [18] }\end{array}$ & $\begin{array}{l}\text { "Jom Cari Kosa Kata" (Let } \\
\text { Look for Vocabulary) }\end{array}$ & $\begin{array}{l}\text { Showed obvious increment. Almost 20.7\% } \\
\text { students used more than ten vocabulary in } \\
\text { the game. }\end{array}$ \\
\hline $\begin{array}{l}\text { Game as a Main } \\
\text { Strategy in Language } \\
\text { Education [19] }\end{array}$ & $\begin{array}{l}\text { Game could be used as an additional } \\
\text { activity in mastering basic language skills } \\
\text { at the primary school level. }\end{array}$ \\
\hline $\begin{array}{l}\text { Mind Challenge game } \\
\text { in video-based } \\
\text { conversation [20] }\end{array}$ & $\begin{array}{l}\text { Card game } \\
\text { "Cabaran Minda" that used } \\
\text { Inquiry Based Learning. }\end{array}$ & $\begin{array}{l}\text { Teachers discovered Mind Challenge game } \\
\text { and followed IBL step-by-step effectively } \\
\text { to help students master the vocabulary. }\end{array}$ \\
\hline
\end{tabular}

Meanwhile, digital approach includes digital material preparation, for example, courseware, application software, social media or mobile application for mobile devices. Regardless of the approach for being analogue or digital, both aim to sustain learners' interests by providing engaging learning materials. To relate with digital approach, study by [21] found that gamification was able to give positive impacts on student learning from various angle especially in students' achievements, involvement and motivation in learning activities. This particular study also highlighted the use of certain game elements such as points and rewards, leader board and digital badges in a gamification application, which can bring positive outcome to any level of students' learning.

Consequently, ICT evolution has opened a new dimension in providing opportunities for exploration, especially in educational technology, that will eventually shape the current T\&L environment [22]. The advent of computer software and hardware has enabled educators and researchers to apply ICT in education. There are numbers of technologies developed for the use of education advancement. Educators and researchers, however, should be wise in choosing the appropriate software and hardware to be embedded in T\&L.

In their study, [23] discovered that in terms of technological, economic and human readiness, secondary school students displayed readiness and had positive perceptions towards using mobile technology for English language literature learning. In addition, [24] emphasised that the effectiveness of the use of mobile technology in learning was due to several factors including learning content, student-content interaction and teacher. Hence, students' age and the level of learning content should be given due consideration.

Further exploration is on the use of mobile application specifically for vocabulary learning. The development of multimedia software is always linked to teaching aid development. A multimedia software for Form One's KOMSAS novel, "Istana Menanti", which is developed by [25] is based on a strategy and learning theories to generate interactive learning environment. The study suggested that teachers do realise the importance of using multimedia software or technology in 
The International Journal of Multimedia \& Its Applications (IJMA) Vol.12, No. 6, December 2020

T\&L. Nevertheless, to develop the technology that can support active learning, teachers need to get some expert's assistance.

Research [26] asserted that some teachers were still comfortable using conventional method in teaching, preferring to rely instead on teacher-oriented method, thus risking students' inner motivation and involvement in the classroom. Although gamification of learning materials greatly benefits the $T \& L$ process, the effectiveness of these materials also depends on whether they are tailored to students' levels, including age and previous knowledge. As stated by [27], the use of game as a means of delivering educational content to the student's consciousness is more effective. A number of studies have proven the effectiveness of gaming and gamification implementation of learning materials across various instructional medium [28][29][30][31]. The studies on the effects of gaming application in the T\&L process are summarised in Table 2 as follows:

Table 2: Effects of Gaming and Gamification Implementation from Multiple Researchers.

\begin{tabular}{|l|l|}
\hline Effect of gaming and gamification implementation & Researchers \\
\hline Increasing knowledge & {$[31],[32],[33],[34],[35],[36]$} \\
\hline Improving visual and motion skills & {$[37],[38]$} \\
\hline Awareness about health care & {$[39],[40]$} \\
\hline Improving technological literacy skill & {$[41],[42]$} \\
\hline Enhancing management and administrative skills & {$[43]$} \\
\hline Social skills & {$[28],[44]$} \\
\hline
\end{tabular}

A research by [45] highlighted that infusing a creative process in the T\&L of vocabulary would make students more autonomous in expanding their knowledge because the practical experience required of creative process which could enhance students' understanding and knowledge retention. The creative process could also divert students' attention to explore something new based on problem solving. Furthermore, [46] suggested that in learning a language, mobile application can be developed by providing interactive learning contents, exercises, and tests in the form of high-quality multimedia elements with a user-friendly interface that integrate fun learning element.

Typically, the development of multimedia software produces T\&L materials unlike those in the traditional T\&L method. The rapid evolution of ICT software and hardware such as tablet, mobile application, and augmented reality has accelerated the use of multimedia software products as teaching aids. The inclusion of multimedia software in the T\&L process has shown positive progress, including in the fields that are lagging behind in technological application. Despite the promising potential of this inclusion, educators, especially those who are still set in their traditional way, may resist from adopting technology in their teaching practice, thus struggle to ensure their students feel engaged and motivated to learn in a traditional classroom setting. As mentioned by [47], in order to fulfil their new roles, teachers must shift their focus in the classroom from lecturing to assessing. As current implementation in Malaysia, the use of technology has helped educators to adapt and develop several learning materials for the students to enrich their vocabulary [48].

\subsection{Game-Based Learning}

In order to understand game-based learning (GBL henceforth), an introduction to gamification is needed to provide an overview of its importance in effective learning. As defined by [49], gamification as a process of turning an activity is not originally a game into a play activity. Gamification refers to the idea of using game principles in a non-gaming situation or activity. For 
The International Journal of Multimedia \& Its Applications (IJMA) Vol.12, No. 6, December 2020

example, the famous café, Starbucks, offer Starbucks Rewards, which works as a reward system to get or redeem complimentary drinks, meals or anything else free-of-charge. Meanwhile, gamebased learning or GBL that relates to the use of game is important in order to enhance learning experience. A good example of a game that fits the criteria of GBL is World of Warcraft, which can be used in Mathematics, History and language subjects. World of Warcraft also encourages communication and writing while developing $21^{\text {st }}$ century skills, such as information and communication skills, thinking and problem-solving skills, and interpersonal and self-guided skills.

Research by [50] claimed that GBL has gained a good reputation among educators because it is perceived as a potential and appealing form of supplementary learning that could enhance the educational process. Besides, it has been used at all levels of education including primary, secondary and tertiary education. GBL consists of two approaches, namely learning by playing games and learning by designing games. The first approach, which is learning by playing games, focuses on the use of existing games or games that are specifically developed to learn a lesson or skill; for example, SimCity game that serves as mechanism for learning financial and business techniques. Meanwhile, learning by designing games focuses on the use of authoring tool to develop a game. The process and skill required in developing this type of game usually involve decision-making and problem-solving techniques in programming and game development.

In T\&L process, gamification has been implemented in the development of learning materials [49]. Gamification in learning materials can increase students' excitement during a learning activity, especially for self-learning. Gamification can also improve motivation level among students during a classroom learning session. According to [51], gamification has been a trending topic as a method in scaffolding user engagement. Moreover, user experience that gained through gamification implementation should be expanded as a new method of conveying knowledge to learners that increases user engagement.

An article reports on the review of 22 articles with three (3) main keywords; 'gamification', 'learning' and 'education' done by [21] showed an interesting finding. [21] highlighted that all the studies with these three keywords show the application of gamification elements as having positive impact on student learning in the context of which they have implemented. As a note, only articles in the form of study or research that clearly state how the elements of gamification applied in teaching and learning activities were taken into account for review done by [21]. They also found out that more studies should focus on exploring gamification among early childhood education, as it is still lacking compared to the developments among school and university students. This statement could be related to a study by [52] who claimed mobile applications have a great potential to enhance early reading skills among young children, as this skill should be mastered by every child in the early age stages.

Based on all previous studies discussed in this section, it is understood that learning materials for Malay vocabulary are lagging in technology adaptation. Hence, this study focuses on developing a teaching material for Malay vocabulary by adopting the 'learning by playing game' approach. In a study by [53], they discovered a significant difference between students who learnt Malay language by using computer application interactively and those who learnt conventionally. Using game as one of the learning activities according to [18] has encouraged students to be active in learning, thus providing a valuable opportunity for educators to train and use language practically and creatively in an exciting environment.

Nonetheless, as reported in a study by [19], some educators perceived game as a non-serious activity. They, however, did not dismiss the potential of GBL and still believed that game could 
The International Journal of Multimedia \& Its Applications (IJMA) Vol.12, No. 6, December 2020

be used as additional activity to ensure the mastery of basic language skills at primary school level. Thus, to play their part, educators and content developers should consider the importance of learning language with GBL adaptation.

\section{Kuasa Kosa Kata (3K) APPliCation Design ANd DeVelopment}

A mobile learning application entitled "Kuasa Kosa Kata" $(3 \mathrm{~K})$ that used to explore the potential of a GBL application was developed with the extracts from 'Sejambak Bakti' novel. The main purpose of this MLA is to enhance the effectiveness of training and comprehension, specifically to improve students' understanding after they had read the novel. The game concepts used were tailored to the Form One students' level, and these include simple approaches such as filling the empty space, drag-and-drop, and looking for hidden things. Research by [54] reiterated that besides a good understanding of educational theories and instructional design system, appropriate instructional models are needed to produce effective learning materials for students to experience a meaningful learning.

Hence, for many years, educators and instructional designers alike have used the ADDIE Instructional Design (ID) as a methodology in designing and developing educational and training programmes [55]. ADDIE is widely accepted as a methodology in developing multimedia application that suits the development of teaching- and instructional-based multimedia software. The acronym ADDIE stands for Analyse, Design, Develop, Implement and Evaluate, which signify the five phases involved in the development of learning material. Thus, this methodology was selected based on the generic processes of developing education application by instructional designers and training industry.

In the Analyse phase, requirement of learner, interface, and content of $3 \mathrm{~K}$ application were identified. The learning needs of Form One students regarding "Sejambak Bakti" novel and the required vocabulary were noted and highlighted. In this phase, the developer had to distinguish between what the students already knew and what they should know after completing the application. The specifications of computer hardware and software to be used were also identified during this phase, in ensuring that the developer had ample time to plan their task completion.

The Design phase focuses on the storyboard, characters, and story design. There is one main character in the novel and a number of other supporting characters. In developing the application, the developer placed the story in three different settings. These settings were selected as the storyboard because they represent a familiar environment to the Form One students;(i) the school supply store; (ii) incident at the school supply store; and (iii) during the school's Appreciation Day. The school supply store setting has detailed the terms in selling and buying activities that usually happened during recess time. The activity designed has required students to identify items that normally found in the supply store, such as pens, pencils, calculators and notebooks.

The second setting featured the incident on a moonlit night when the supply store was broken into. The moonlight was bright enough for a witness to make out the figure of the thief. The morning after the robbery, the worker at the school supply store found the supply store in a mess. Developing the digital scene for this setting was quite challenging as the designer had to create the characters with intense facial expressions that caused by the shocking incident. Finally, the school's Appreciation Day was designed as a pleasurable event. This is also an incentive for all parties who responsible in generating high profits for the school supply store. Designing all the characters and items in the environment in those three scenes was not an easy task, but still achievable. 
The International Journal of Multimedia \& Its Applications (IJMA) Vol.12, No. 6, December 2020

Next, the Develop phase promptly took place after the Analysis and Design phases. The development stage is about putting all the planning and brainstorming idea into action. It involves creating and testing the learning outcomes of the topic. The development of each story in the $3 \mathrm{~K}$ application was done using the Adobe Flash software as it offered the best means to publish the final product. The software provided the best character drawing and suited the storyboard drawn earlier. The characters were drawn using Adobe Illustrator and edited with Adobe Photoshop. Once the application comprising all the three stories that were developed, formative evaluation was done as advocated by the ADDIE model. Main interface for $3 \mathrm{~K}$ application was purposely to put in colour as to rise the interest of secondary school student to learn using the application, as shown in Figure 1.

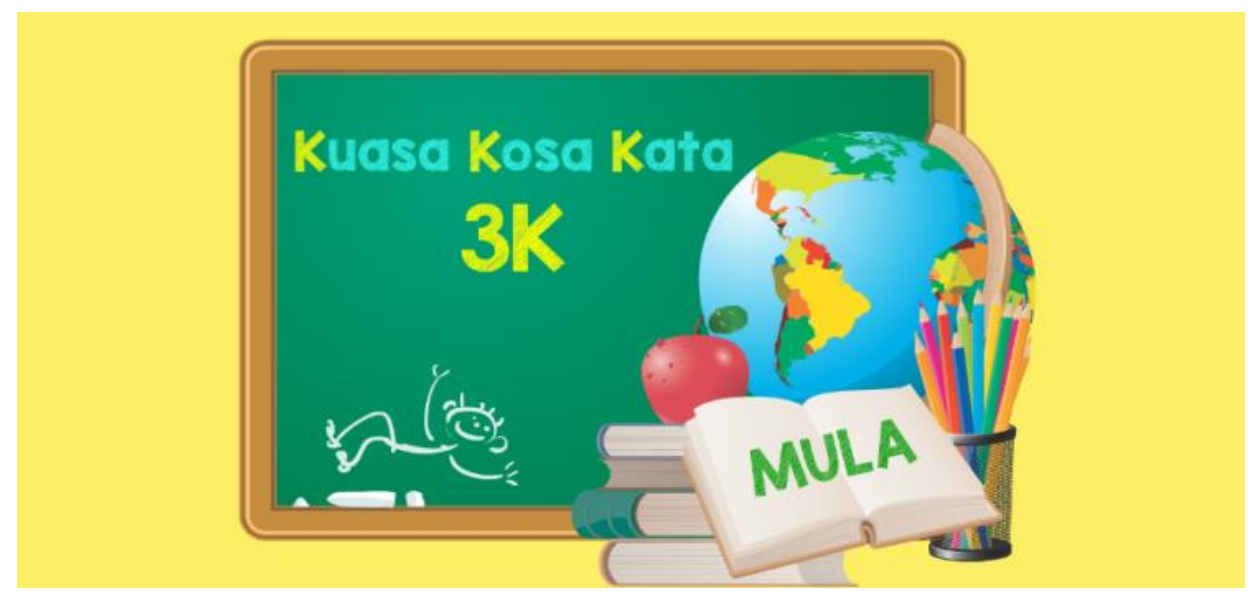

Figure 1. Main Interface for 3K Application

In the Implementation phase, it involved the employment of $3 \mathrm{~K}$ mobile learning application among selected participants at their convenient time, which was outside of school session. The early plan was to select up to twenty students for this phase. However, due to a number of comments towards prototype, the researchers only managed to select only ten (10) students. Two weeks prior to approaching the students, the researcher asked the selected students' parents for consent on behalf of their children. The students (or participants in this context) had agreed to participate in this study as they realised the need of learning Malay language using additional learning material. Installation of the app was done at two (2) handheld device (which are Android tablets) and the participants were supplied with the devices, by taking their turn one after another. They were given almost 15 minutes of time to navigate $3 \mathrm{~K}$ application in order to explore the application independently on different time and day. After the navigation, semi-structured interview questions were proposed as agreed before.

The final phase is the Evaluate phase. The objective of the evaluation stage is to determine whether the goals have been accomplished, and to determine whether the application is efficient. Evaluation is an essential step in the ADDIE method as it aims to answer important questions regarding effectiveness, data collection approach, participant's feedback, clarity of instruction in the application, and many more. It reflects continuous amendment of this application prototype to ensure that utmost efficacy is obtained.

\section{FindingS}

This study utilised qualitative data collection and analysis within the design and development research design. The rationale for utilising this method was to obtain in-depth responses 
The International Journal of Multimedia \& Its Applications (IJMA) Vol.12, No. 6, December 2020

regarding the mobile learning application by selected participants. It also allowed more freedom for the participants to express their opinions regarding the application. For this study, semistructured interviews with the participants had been conducted during the Evaluation phase.

\subsection{Demographic of Participant}

Altogether, for preliminary testing, there were ten (10) Malaysian secondary school students, resided in a southern rural city in Perak, Malaysia had been selected as participants. The participants were selected using a purposive sampling technique from secondary school student, starting with those who were voluntarily participated during their free time, with their parents' consent. All of them were Form One students which their school as well as their homes were situated approximately within 15 kilometres from the venue of researchers' workplace. The main reason they were selected is because of their literacy in using handheld device, as well as their enthusiasm in using a game-based learning method. There were six (6) girls and four (4) boys involved, ranged from ages of 12 and 13 years old. All of them gave good cooperation throughout the interview session after using the mobile learning application on the mobile device provided for testing phase. Time taken was averagely 9 to 15 minutes for each participant to complete the interview session right after using the $3 \mathrm{~K}$ application. The demographic of participant was simplified in Table 3 as follows.

Table 3: Demographic of Participants of Study.

\begin{tabular}{|l|l|l|l|l|}
\hline Participant & Age & Gender & $\begin{array}{l}\text { Average time taken for } \\
\text { navigation }\end{array}$ & $\begin{array}{l}\text { Average time for } \\
\text { interview session }\end{array}$ \\
\hline P1 & 12 & Male & 11 minutes & 9 minutes \\
\hline P2 & 12 & Male & 13 minutes & 10 minutes \\
\hline P3 & 13 & Female & 12 minutes & 10 minutes \\
\hline P4 & 12 & Female & 13 minutes & 12 minutes \\
\hline P5 & 12 & Male & 12 minutes & 12 minutes \\
\hline P6 & 12 & Female & 14 minutes & 13 minutes \\
\hline P7 & 12 & Female & 12 minutes & 13 minutes \\
\hline P8 & 12 & Female & 15 minutes & 14 minutes \\
\hline P9 & 13 & Female & 11 minutes & 11 minutes \\
\hline P10 & 13 & Male & 10 minutes & 10 minutes \\
\hline
\end{tabular}

\subsection{Feedback from Participant}

To detail up this section, there are two (2) research questions that need to be evoked, which can be found as follows:

i) how do students feel when using $3 \mathrm{~K}$ application in learning Malay vocabulary?

ii) what suggestion(s) that students want to propose in improving $3 \mathrm{~K}$ application?

For the first questions, all of the participants showed positive attitude towards learning Malay vocabulary using $3 \mathrm{~K}$ mobile learning application. They were more focused and inspired in learning when using the GBL application through mobile devices. This attitude reflects technological readiness, with regards to the technological devices owned and the way they are being used [23]. The participants found out that $3 \mathrm{~K}$ mobile learning application was interesting and made them triggered to learn and focus from the beginning until the end of the application. They also agreed that the interface design was attractive. In term of colour, most participants agreed on the wise use of colour combination that managed to influence their enthusiasm to finish 
up three (3) different settings in the application. In terms of sound, it helped the participants by guiding them in answering the questions throughout the application.

Remarkably, the participants claimed that they learnt new vocabulary from three different stories in the $3 \mathrm{~K}$ application. Some of the words were 'berganding bahu' (joint venture), 'menyusup keluar' (infiltrated), 'tepukan gemuruh' (big applause) and 'pengiktirafan khas' (special recognition). They further admitted that their confidence in the Malay language had increased as they had new vocabulary to be used in writing composition. The participants also showed their interest to learn more as they enjoyed game-based learning implementation in the application. Additionally, most of them agreed to repeatedly use $3 \mathrm{~K}$ application after reading "Sejambak Bakti” novel for KOMSAS.

\subsection{Suggestion by Participant for Further Improvement}

Since this study was still in early phase, the researcher was looking forward to getting suggestion and comment from the participants. There were three (3) participants who suggested for more content in the $3 \mathrm{~K}$ application, as they said three stories were not enough to explore the application further. They also suggested for more game-based activities in order to enhance understanding for 'Sejambak Bakti' novel and add more Malay vocabulary for extra use in future. In terms of technical elements, the participants offered some suggestions for improvements. For example, they proposed for audio enhancement for the second story (at the sports equipment storage room) by adding the sound of thunder to visualise the real situation of a heavy rain night. They also urged to add a suitable gaming option in the third story (during the school's Appreciation Day). Essentially, some modifications are needed to ensure the $3 \mathrm{~K}$ application would attain its greater effectiveness for Malay vocabulary learning.

\section{Conclusions}

This study reinforced the applicability of development of Malay vocabulary game-based learning. By applying the learning approach of game-based learning, it has instilled students' motivation and interests to learn on Malay vocabulary. From this study, it can be concluded that it is important to develop more learning material in Malay vocabulary in order to embed game-based learning in the T\&L activity.

\subsection{Contribution}

It is obvious that game-based learning (GBL) application provides an interesting learning environment for secondary school students as they are given the opportunity to navigate the application without interruption at their own time and place. This situation can foster activelearning process among low secondary school students, as well as encourage readiness to learn without being forced by their parents at home, or teachers at school. At the same time, the Internet is an indispensable resource in the exploration of knowledge in this knowledge explosions era. Hence, the advancement of ICT has created new learning environments that allow for more flexibility in time, place, method, and teaching and learning materials [5].

Furthermore, students can improve their confidence level by using the new vocabulary when they practice writing composition. Students should certainly be prepared to adapt to the use of ICT in learning technology, economy and competency, so that teachers will be able to create a new learning environment as well as promote positive aspects of ICT, such as being a means of lifelong learning [23]. 
The International Journal of Multimedia \& Its Applications (IJMA) Vol.12, No. 6, December 2020

In addition, [21] pointed out that implementation of GBL should be widely implemented by educators in $\mathrm{T} \& \mathrm{~L}$ process. The $\mathrm{T} \& \mathrm{~L}$ session conducted by the teacher in class is also positively affected, as students are more attentive of the teacher's effort in delivering vocabulary lesson in Malay language with the help of $3 \mathrm{~K}$ application. Through proper documentation as SDG, [4] believed that teachers obviously need to upgrade their qualification, knowledge and skill simultaneously, especially in preparing learning materials for their students. Moving from the primary school environment to secondary school level can affect students' feelings towards language learning positively or negatively. In the case of the latter, game-based learning implementation could assist in creating an exciting learning environment and also helping students to manage their anxiety.

\subsection{Limitation}

The participants agreed that they could use the $3 \mathrm{~K}$ application as a learning material at home once they install it in their mobile devices, either on a smart phone or tablet. This self-learning approach preferrable, as they could learn at their own pace. However, they need to obtain permission from their parents, as not all of them possess their own mobile devices. Not owning a mobile phone definitely hinders them from participating in the home learning sessions as they need to share the devices with their guardians or siblings. This situation, however, can be easily resolved if they manage to get their own mobile devices, sooner or later. Another limitation is identified through the content for $3 \mathrm{~K}$ application that solely suitable for Form One secondary school students in Malaysia government school, as the element was taken from dedicated novel according to their form.

\subsection{Recommendation}

This stage of testing analysis of $3 \mathrm{~K}$ mobile application prototype has revealed a significant finding: There is the need of more T\&L material in digital form for secondary school students in Malaysia government schools. Since there are teachers who have been criticised for the lack of sufficient knowledge of the required design processes and methods to develop a T\&L digital teaching material with GBL approach, developers should take responsibility to design and develop respective T\&L digital material for the teachers' use in order to improve current T\&L practice [56][57]. At the same time, teacher, especially Malay language expert teacher, should be provided with opportunity to learn and enhance their knowledge regarding gamification implementation, so that they can deliver an impactful learning experience to their learners.

As highlighted by [58], the developers should examine the appropriateness of game element for each learning app and set a game concept that suitable to be used by users in a way to achieve the goal of using educational games-based apps in any mobile application developed. It is hoped that the use of $3 \mathrm{~K}$ mobile application will boost the mastery of Malay language vocabulary among lower secondary school students. Future study could also involve a larger pool of participants with a focus on getting their opinions on the GBL application's functionality and usability.

\section{ACKNOWLEDGEMENTS}

The authors would like to thank Research Management and Innovation Centre (RMIC), Universiti Pendidikan Sultan Idris (UPSI) for supporting this study under the University Research Grant (Research Code: 2016-0045-109-01)] and all participants who were involved in this research. 
The International Journal of Multimedia \& Its Applications (IJMA) Vol.12, No. 6, December 2020

\section{REFERENCES}

[1] Sharples, M., Taylor, J., \& Vavoula, G. (2006). A theory of learning for the mobile age. In R. Andrews and C. Haythornthwaite (eds.). The Sage Handbook of Elearning Research. London: Sage, pp. 221-247.

[2] Mohd Shahrizal Nasir, Mohd Firdaus Yahaya, Mohd Fauzi Abdul Hamid \& Muhammad Sabri Sahrir. (2016). An analysis of student's response towards the design of Arabic Language E-Learning platform through EZ Arabic.net for primary school students. Jurnal Sultan Alauddin Sulaiman Shah, Vol. 3, No. 2, pp. 1-18.

[3] Ummu Husna Azizan, Maizatul Hayati Mohamad Yatim, Laili Farhana Md Ibharim \& Nor Zuhaidah Mohamed Zain. (2019). Analysis of game elements in digital educational game according to Gagne nine events of instruction. International Journal of Academic Research in Business and Social Sciences, Vol. 9, No. 7, pp. 131-135.

[4] United Nation Educational, Scientific and Culture Organization. (2020). Quality Education. Retrieved February, 22020 from https://www.un.org/sustainabledevelopment/education/

[5] Malaysia Ministry of Education. (2013). Pelan Induk Pembangunan Pendidikan 2013 - 2025. Putrajaya: Ministry of Education.

[6] Ani Omar \& Rosnidar Mansor. (2019). ICT influence in teaching and facilitation of Malay literature for increasing $4 \mathrm{~K}$ thinking. In $8^{\text {th }}$ UPI-UPSI International Conference (UPI-UPSI 2018). Advances in Social Science, Education and Humanities Research, Vol. 239, pp. 185-190.

[7] Abdull Shukor Shaari, Nuraini Yusoff, Mohd Izam Ghazali \& Mohd Hasani Dali. (2011). Kanakkanak minoriti orang asli di Malaysia: menggapai literasi Bahasa Melayu. Jurnal Pendidikan Bahasa Melayu, Vol. 1, No. 2, pp. 59-70.

[8] Ellianie Sahrom \& Nur Hidayu (2015). Pembelajaran kosa kata melalui papan permainan. Seminar Bahasa Melayu. Jurnal Pengajian Melayu, Vol. 6, pp. 37-54.

[9] Nurul Akhmal Mohd Zulkefli, Haslinda Hashim, Azniah Ismail \& Juraini Jamaluddin. (2018). Effects of using virtual learning environment in teaching and learning Malay language. The International Journal of Multimedia \& Its Applications, Vol. 10, No.6, pp. 13-25.

[10] Hasrina Baharum, Norazimah Zakaria, Nordiana Hamzah \& Ariff bin Mohamad. (2018). Pendidikan kepelbagaian budaya dalam sejambak bakti. Jurnal Melayu Sedunia, Vol. 1, No. 1, pp. 210-232.

[11] Hasrina Baharum. (2016). Sejambak Bakti, novel Komponen Sastera (KOMSAS) Tingkatan 1 sebagai sumber kesusasteraan pelbagai budaya dalam pendidikan kepelbagaian budaya untuk pelajar: satu tinjauan. Proceeding of the $1^{\text {st }}$ International Teacher Education Conference on Teaching Practice, Universiti Pendidikan Sultan Idris, Malaysia, pp. 515-526.

[12] Subadrah Nair \& Rajeswari Arumugam. (2006). Keberkesanan kaedah model skema bagi meningkatkan kefahaman dan minat pelajar terhadap cerpen Bahasa Melayu. Malaysian Journal of Learning and Instruction, Vol. 3, pp. 65-92.

[13] Shamsudin Othman. (2014). Penggunaan bahasa sastera dalam pengajaran Bahasa Melayu di sekolah menengah. Jurnal Pendidikan Bahasa Melayu. Vol. 4, No. 1, pp. 59-64.

[14] Nik Hassan Basri Nik Ab. Kadir. (2005). Pengajaran gaya bahasa dalam Bahasa Melayu. Jurnal Pengajian Melayu, Vol. 16, pp. 37-54.

[15] Smaldino, S. E., Lowther, D. L., Mims, C. D., \& Russell, J. D. (2014). Instructional Technology and Media for Learning. New Jersey: Pearson Education Inc.

[16] Bakhsh, Sahar A. (2016). Using games as a tool in teaching vocabulary to young learners. English Language Teaching, Vol. 9, No. 7, pp. 120-128.

[17] Nor Hashimah Jalaluddin, Junaini Kasdan \& Zaharani Ahmad. (2010). Sosiokognitif pelajar remaja terhadap bahasa melayu. GEMA Online Journal of Language Studies, Vol. 10, No. 3, pp. 67-87.

[18] Ilangko Subramaniam. (2014). Aktiviti permainan bahasa, wahana penguasaan kosa kata. Jurnal Pendidikan Bahasa Melayu, Vol. 4, No. 2, pp. 1-9.

[19] Birova, Ilka L. (2013). Game as a main strategy in language education. American Journal of Educational Research, Vol. 1, No. 1, pp. 6-10.

[20] Noor Zanariah Sidi \& Norizan Mohamad Nor. (2015). Permainan cabaran minda dalam perbualan berdasarkan video. Seminar Bahasa Melayu. Retrieved June 21 ${ }^{\text {st }} 2019$ from https://academyofsingaporeteachers.moe.edu.sg/docs/librariesprovider6/ml-poetry-sg50/seminarbahasa-melayu-2015/kertas-kerja-sesi-sidang-selari/32_seminarpapers.pdf 
The International Journal of Multimedia \& Its Applications (IJMA) Vol.12, No. 6, December 2020

[21] Mohd Hishamuddin Abdul Rahman, Ismail @ Ismail Yusuf Panessai, Noor Anida Zaria Mohd Noor \& Nor Syazwani Mat Salleh. (2018). Gamification elements and their impacts on teaching and learning - a review. The International Journal of Multimedia \& Its Applications, Vol. 10, No.6, pp. $37-46$.

[22] Maizatul Hayati Mohamad Yatim, Laili Farhana Md. Ibharim \& Md. Nasir Masran. (2014). "Pendekatan pembelajaran melalui reka bentuk permainan digital dalam proses pengajaran dan pembelajaran kanak-kanak: Isu dan cabaran". Proceedings of the 5th International Conference Educational Technology Adibuana. Surabaya, Indonesia.

[23] Rashidah Rahamat, Parilah M. Shah, Rosseni Din \& Juhaida Abd Aziz. (2017). Students' readiness and perceptions towards using mobile technologies for learning the English language literature component. The English Teacher. XL, pp. 69-84.

[24] Wan Mohd Amir Fazamin Wan Hamzah, Hafiz Yusoff \& Ismahafezi Ismail. (2020). The behavioural intentions of secondary school students to use tablet as a mobile learning device. International Journal of Interactive Mobile Technologies, Vol. 14, No, 13, pp. 161-170.

[25] Zamri Mahamod \& Nur Aisyah Mohamad Noor. (2011). Persepsi guru tentang penggunaan aplikasi multimedia dalam pengajaran komponen sastera Bahasa Melayu. GEMA Online Journal of Language Studies, Vol. 11, No. 3, pp.163-177.

[26] Salmiza Saleh and Afik Aziz. (2012). Teaching practices among secondary school teachers in Malaysia. International Proceedings of Economics Development and Research. Vol. 47, pp. 63-67.

[27] Liu, Zi-Yu, Ahmed Shaikh, Z. \& Gazizova, F. (2020). Using the concept of game-based learning in education. International Journal of Emerging Technologies in Learning, Vol. 15, No. 14, pp. 53-64.

[28] Dorji, U., Panjaburee, P., \& Srisawasdi, N. (2015). Gender differences in students' learning achievements and awareness through residence energy saving game-based inquiry playing. Journal of Computers in Education, Vol. 2, No. 2, pp. 227-243.

[29] Wainwright, M. (2014). Teaching historical theory through video games. The History Teacher, Vol. 47, No. 4, pp. 579-612.

[30] Nunohiro, E., Matsushita, K., Mackin, K.J. \& Ohshiro, M. (2013). Development of game-based learning features in programming learning support system. Artificial Life and Robotics, Vol. 17, No. 3-4, pp. 373-377.

[31] Roslina Ibrahim, Rasimah Che Mohd Yusoff, Hasiah Omar \& Azizah Jaafar. (2011). Students perceptions of using educational games to learn introductory programming. Computer and Information Science, Vol. 4, No. 1, pp. 205-216.

[32] Jong, M.S.Y. (2015). Does online game-based learning work in formal education at school? A case study of VISOLE. The Curriculum Journal, 5178, pp. 1-19.

[33] Foster, A. \& Shah, M. (2015). The play curricular activity reflection discussion model for gamebased learning. Journal on Research on Technology in Education, Vol. 477, No. 2, pp. 71-88.

[34] Choi, Y.S. (2014). Effectiveness of game based learning to minimize boolean functions. Multimedia Tools and Applications, pp. 7131-7146.

[35] Liu, M., Rosenblum, J.A., Horton, L., \& Kang, J. (2014). Designing science learning with gamebased approaches. Computers in the Schools, Vol. 31, No. 1-2, pp. 84-102.

[36] Martin, M.W. \& Shen, Y. (2014). The effects of game design on learning outcomes. Computers in the Schools, Vol. 31, No. 1-2, pp. 23-42.

[37] Appelbaum, L.G., Cain, M.S., Darling, E.F., \& Mitroff, S.R. (2013). Action video game playing is associated with improved visual sensitivity, but not alterations in visual sensory memory. Attention, Perception \& Psychophysics, Vol. 75, No. 6, pp. 1161-1167.

[38] Bailey, K. \& West, R. (2013). The effects of an action video game on visual and affective information processing. Brain Research, 1504, pp. 35-46.

[39] Hocine, N., Gauaich, A., Cerri, S.A., Mottet, D., Froger, J., \& Laffont, I. (2015). Adaptation in serious games for upper-limb rehabilitation: An approach to improve training outcomes. User Modeling and User-Adapted Interaction, Vol. 25, No. 1, pp. 65-98.

[40] Hannig, A., Kuth, N., Ozman, M., Jonas, S., \& Spreckelsen, C. (2015). eMedOffice: A web-based collaborative serious game for teaching optimal design of a medical practice. BMC Medical Education, Vol. 21, No. 1, pp.104.

[41] Wu, M.L., Richards, K. \& Saw, G.K. (2014). Examining a massive multiplayer online role-playing game as a digital game-based learning platform. Computers in the Schools, Vol. 31, No. 1-2, pp. 6583. 
The International Journal of Multimedia \& Its Applications (IJMA) Vol.12, No. 6, December 2020

[42] Kordaki, M., Papastergiou, M., \& Psomos, P. (2014). Student perceptions in the design of a computer card game for learning computer literacy issues: A case study. Education and Information Technologies. Retrieved June 82017 from http://www.amazon.com/Instructional-TechnologyLearning-Enhanced-Loose-Leaf/dp/0133831655

[43] Chee, Y.S., Mehrotra, S. \& Ong, J.C. (2014). Authentic game-based learning and teachers' dilemmas in reconstructing professional practice. Learning, Media and Technology, Vol. 9884, No. 2001, pp. 137.

[44] DeVane, B. (2014). Beyond the screen: Game-based learning. T.H.E. Journal, Vol. 33, No. 6, pp. 3033.

[45] Siti Rohani Jasni, Suhaila Zailani@ Ahmad \& Hakim Zainal. (2020). Impak pendekatan kreatif dalam pengajaran dan pembelajaran kosa kata Arab. BITARA International Journal of Civilizational Studies and Human Sciences, Vol. 3, No. 1, pp. 010-021.

[46] Wan Ab Aziz Wan Daud, Wong Kung Teck, Mohammad Taufiq Abdul Ghani \& Saipolbarin Ramli. (2019). The needs analysis of developing mobile learning application for cybergogical teaching and learning of Arabic language proficiency. International Journal of Academic Research in Business and Social Sciences, Vol. 9, No. 8, pp. 33-46.

[47] Keiler, Leslie S. (2018). Teachers' roles and identities in student-centered classrooms. International Journal of STEM Education, Vol. 5, No. 3, pp. 1-20.

[48] Chai Kar Ni, Bonaventure Jong, Mary Anne Dison, Sylvia Anak Thomas, Melor Md Yunus \& Ashairi Suliman. (2020). Enhancing Malaysian primary pupils' vocabulary skills using pocable game and pear deck. International Journal of Learning, Teaching and Educational Research. Vol. 19, No. 6, pp. 145-160.

[49] Tan, W.H. (2015). Gamifikasi dalam pendidikan: Pembelajaran berasaskan permainan. Tanjong Malim: Penerbit UPSI.

[50] Hainey, T., Conolly, T.M., Boyle, E. A., Wilson, A. \& Razak, A. (2016). A systematic literature review of games-based learning empirical evidence in primary education. Computers \& Education, Vol. 102, pp. 202-223.

[51] Auwalu Rabiu Ali, Azizah Endut \& Rahimah Embong. (2018). Attitude of undergraduate students towards gamification: a case study of Northwest Geo-Political Zone, Nigeria. Journal of ICT in Education, Vol. 5, pp. 9-13.

[52] Abdul Jalil Mohamad \& Muhammad Modi Lakulu. (2017). A framework of mobile educational application for kindergarten early reading. The International Journal of Multimedia \& Its Applications, Vol. 9, No.4/5/6, pp. 113-119.

[53] Yahya Othman \& Dayang Raini Pakar (2011). Kesan perisian cerita interaktif semasa mengajarkan kemahiran bacaan dan kefahaman dalam kalangan pelajar tahun 4 di Brunei Darussalam. Jurnal Pendidikan Bahasa Melayu, Vol. 1, No. 1, pp. 27-49.

[54] Mohammad Taufiq Abdul Ghani \& Wan Ab Aziz Wan Daud. (2018). Adaptation of ADDIE instructional model in developing educational website for language learning. Global Journal of AtThaqafah, Vol. 8, No. 2, pp. 7-16.

[55] Kurt, S. (2017). ADDIE Model: Instructional Design in Educational Technology. Retrieved August $29^{\text {th }}$., 2018 from https://educationaltechnology.net/the-addie-model-instructional-design/

[56] Mohd Syazwan Wan Mahzan, Nor Aziah Alias \& Izaham Shah Ismail. (2020). Investigating the needs of developing a digital vocabulary learning material for Malaysian indigenous learners in ESL classroom. Journal of Nusantara Studies, Vol. 5, No. 2, pp. 282-302.

[57] Nor Hasbiah Ubaidullah, Aizu Khalili Zohedi \& Norasikin Fabil. (2017). Development of a new application for multimedia learning with animation exaggeration based on ADDIE model. The International Journal of Multimedia \& Its Applications, Vol. 9, No.4/5/6, pp. 39-49.

[58] Noor Asmina Mohd Rashid, Shaharuddin Md Salleh \& Norah Md Noor. (2018). The role of game elements in improving Jawi skills through a mobile game 'G-Jawi'. International Journal of Interactive Mobile Technologies. Vol. 12, No. 7, pp. 20-29. 
The International Journal of Multimedia \& Its Applications (IJMA) Vol.12, No. 6, December 2020

\section{AUTHORS}

Nor Zuhaidah Mohamed Zain is a lecturer at Faculty of Art, Computing and Creative Industry at Universiti Pendidikan Sultan Idris, Malaysia. Received her Master of Science (Information Technology) from MARA University of Technology in 2005, her research interests lie in the area of Multimedia Learning in Education, HumanComputer Interaction and implementation of Mobile Learning, focusing on Special Education needs.

Maizatul Hayati Mohamad Yatim is an associate professor at Faculty of Art, Computing and Creative Industry, Universiti Pendidikan Sultan Idris, Malaysia. Received her Doctor of Philosophy in Computer Science (Human-Computer Interaction) from Otto-Von-Guericke University of Magdeburg, Germany in 2009, her research interests are Human-Computer Interaction, IT Project Management, Multimedia in Education, Edutainment and Children and Games Design \& Development.

Ummu Husna Azizan is a senior lecturer at Faculty of Art, Computing and Creative Industry at Universiti Pendidikan Sultan Idris, Malaysia. Awarded a Doctor of Philosophy in Information Technology in Education at Universiti Sains Malaysia in 2015, her research areas include technology in education, game-based learning, multimedia in education and instructional technology.

Hasrina Baharum is a senior lecturer at Faculty of Language and Communication at Universiti Pendidikan Sultan Idris, Malaysia. Awarded a Doctor of Philosophy in Malay Literature from Universiti Sains Malaysia in 2015, her research areas include Malay Literature, Traditional Malay Literature as well as book and magazine publication.
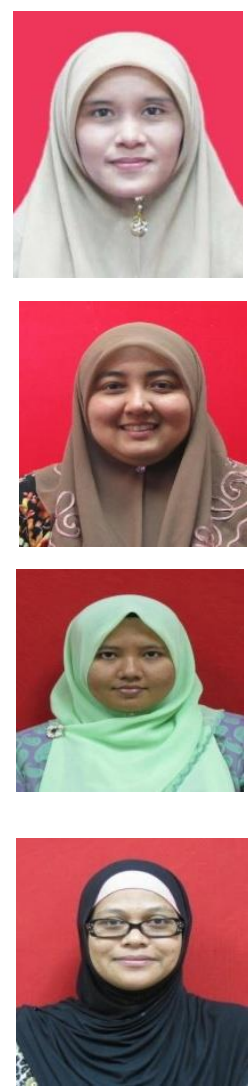